\title{
A comparative analysis of freeway design in Portugal and Mexico
}

\author{
Lígia Conceição ${ }^{1}$, Carlos Rodrigues ${ }^{1,2}$ \\ ${ }^{1}$ Department of Civil Engineering, Faculty of Engineering, University of Porto, R. Dr. Roberto \\ Frias, s/n, 4200-465 Porto, Portugal (up200907654@fe.up.pt); ${ }^{2}$ CITTA - Research Centre for \\ Territory, Transports and Environment, Porto, Portugal (cmr@fe.up.pt)
}

\begin{abstract}
Freeways typify accessibility, which is a parameter related to the development of a country. A developing country, such as Mexico, is concerned with an emergent construction market of freeways, which has been a target for Portuguese construction companies since the Portuguese economic and construction crisis in 2008.

In the earlier stages of a freeway project, the ubiquitous use of software calculations along with geometric standards restrictions is performed automatically and may introduce loss of sensitivity to the designer.

This paper addresses this concern by presenting a Standards comparison between Mexico and Portugal, focusing on the elements of design and a comparative multicriteria analysis adapted from Kalamaras et al. (2000). Through six case studies, this paper analyses the Standards' influence on the horizontal alignment outcome, the radial uncompensated accelerations and the Brückner curves, concluding with the multi-criteria analysis results.
\end{abstract}

Subject Headings. Transport Policy, Expressway, Public Works, Deregulation, Road Building, Construction Policy

Author Keywords. Highway Engineering, Geometric Design, Standards, Freeways Comparison, Portugal, Mexico

\section{Introduction}

The term freeway appeared in the last century, after World War I, and its implementation was fostered by the job creation and the military (Vahrenkamp 2010) which resembles to the quick movement of troops, the strategic purpose of the Roman Empire. High speed is usually a parameter linked to this type of highway due to the free flow conditions traffic requirement. The first freeway was inaugurated in 1920 in the USA; but the first cement paved freeway section was former introduced in 1908 by a race-loving entrepreneur for himself. European countries, such as Germany and Italy, implemented these high-speed roads in the late 20s; due to railway hegemony, the United Kingdom only implemented them in the 50s.

In Portugal, the first freeway section was only 8 kilometres long, constructed in 1944 in Lisbon. However, the connection between the two major cities (Lisbon and Porto) only happened in 1982 at the beginning of the democratic political regime. The exponential construction of freeways can be observed with regards to the full length in kilometres over time: in the 60's, there existed $40 \mathrm{~km}$ of freeways; in 1988, $235 \mathrm{~km}$; in 1992, $1408 \mathrm{~km}$; in 2001, $2875 \mathrm{~km}$ (Pacheco 2001). Today, there is an estimated 2737 kilometres of freeways (ERF 2015), which indicates a massive recent expansion in freeway construction. 
Since the 2008 global economic crisis, the Portuguese economy has been severely unstable, with the construction industry being the major sector affected. Many civil companies were forced to go out of business and others internationalized, primarily the ones specialized in the construction of freeways. Once Mexico gathered an emergent construction market to improve self-development through accessibility, the link between Portuguese companies and the Mexican Government strengthened.

During project conception, the ubiquitous use of highway design software leads to an unawareness about the differences between standards and their outcomes. This study clarifies the lack of sensitivity of a designer that works with both standards (Mexican and Portuguese) which, at some point during project conception, needs to make an accurate decision.

There are three primary pieces of evidence that bring awareness to this topic of study. First, a road network expansion is intrinsically linked to a country's development. For instance, during the Roman Empire (27 BC to $476 \mathrm{AC}$ ), road construction expertise was vital for army expansion and thus their social and economic progress. Second, all existing knowledge and techniques were collected over millions of years of human civilization, with some stagnant periods due to political, economic or social crises. Thus, there is an enormous potential for advancement due to actual technology and existent worldwide peace. One historical fact is that after the Roman Empire declined, roadway engineering improved only in the middle ages, especially during the industrial revolution. Finally, current global development and networks encourage underdeveloped countries to expand their transport networks, e.g., freeways, to boost commerce and economic growth.

This study was proposed by a Portuguese consultancy company, GEG (Gabinete de Estruturas e Geotecnia), which reinforces the aim of this study (Pereira 2014).

A road network comprises arterial systems, collector systems and local road systems that balance between mobility and accessibility. A freeway is normally classified as a principal arterial system, although it is not a functional class itself. However, it is usually allied with mobility once it can guarantee movement between urban areas with populations of over 25,000 and also 50,000 with respect to the level of service assumed (AASHTO 2011). The summary definition of a freeway is an arterial system within which motor vehicles can circulate at high speeds in two directions of traffic within a separated corridor and with no level intersections.

According to the last Portuguese standard revision (InIR 2008), freeways may be classified in four categories:

- Interurban freeway, for traffic of medium and long distances (access nodes spaced 8 $\mathrm{km}$ apart)

- Interurban freeway in difficult topography, similar to the last definition but in rough terrain and with lengths over $10 \mathrm{~km}$ (access nodes spaced $8 \mathrm{~km}$ apart)

- Suburban freeway, part of the National Roadway Plan, PRN (2000), located in the urban periphery and serving interurban traffic (traffic pendular) around a metropolitan area (access nodes: $2 \mathrm{~km}$ )

- Urban freeway, part of the National Roadway Plan, PRN (2000), situated in urban zones and diffusing metropolitan traffic into interurban zones (access nodes: $1.5 \mathrm{~km}$ ).

It is important to denote that InIR (2008) is a document not formally approved but its use in Portugal is subject to "Infraestruturas de Portugal" entity approval. In fact, this is an 
adaption from the previous Portuguese standard (JAE 1994). Therefore, it may contain some contradictory parameters, however the current paper does not hold that issue.

According to the Mexican standard manual (SCT 1991), freeways correspond to arterial systems that are classified as two types (A4 or A4S) (SCT 2004):

- "autopistas" - similar to freeways, they have at least two lanes in each direction and a Daily Traffic Average Annual (TDMA) of over 5,000 vehicles

- "vías rápidas" - similar to interstates, they have less requirements and a Daily Traffic Average Annual (TDMA) between 3,000 and 5,000 vehicles.

In Mexico, despite the primary function of mobility carried by the concept of freeway in free flow conditions, particular entrances that connect farms and houses to the freeway are quite common; thus, level intersections do not seem to be a restriction.

Therefore, to describe the differences between a freeway project in Mexico and in Portugal, the comparative analysis is introduced by a standards analysis and, subsequently, a multicriteria analysis that includes three main criteria: geometry, safety, and user viewpoint. Afterward, designed case studies and a comparison with respect to the horizontal alignment outcome, the radial uncompensated accelerations, a Brückner curves comparison as well the results from the multi-criteria analysis application are presented.

\section{Freeway Design Comparison}

The freeway design comparison is settled in two stages. The first relays the standards analysis to verify the dissimilarities in each element design. Both standards are critically analysed among the design theories and the minimum admissible values that result from preceding requirements. The second stage of this freeway design comparison proposes a multi-criteria analysis that includes a hierarchical sensibility analysis to maximize operational functionality. The criteria represent the stakeholders that the project design, in some way, influences: the design engineer, the concessionary company responsible for maintenance and the user (i.e., the drivers).

\subsection{Standards comparison}

Despite the temporal distance between the Mexican standards (SCT 1991, 1984) and the Portuguese standards (InIR 2010, 2008), both arise from common design theories and are well organized with respect to several elements of design approaches. In this study, the most important elements of design are distinguished in four topics: the sight distance, the horizontal alignment, the vertical alignment and the cross-section elements.

The initial parameter required, also called the design control, is the design speed. Despite the minimum design speed of a freeway being $80 \mathrm{~km} / \mathrm{h}$ (50 mph) in both countries, the maximum value of design speed is $110 \mathrm{~km} / \mathrm{h}$ (65 mph) in Mexico and $140 \mathrm{~km} / \mathrm{h}$ (85 mph) in Portugal, limiting this study to $110 \mathrm{~km} / \mathrm{h}$. Moreover, there are two other types of speed used in freeway design: the operating speed, which is in free-flow conditions, matching the $85^{\text {th }}$ percentile distribution of observed speeds, and the running speed, at which a vehicle travels over a section depending on the traffic that Mexican standards consider as off-peak hour traffic. Table 1 shows the speed criteria in each element of design, and Table 2, the quantitative relation of speeds. 


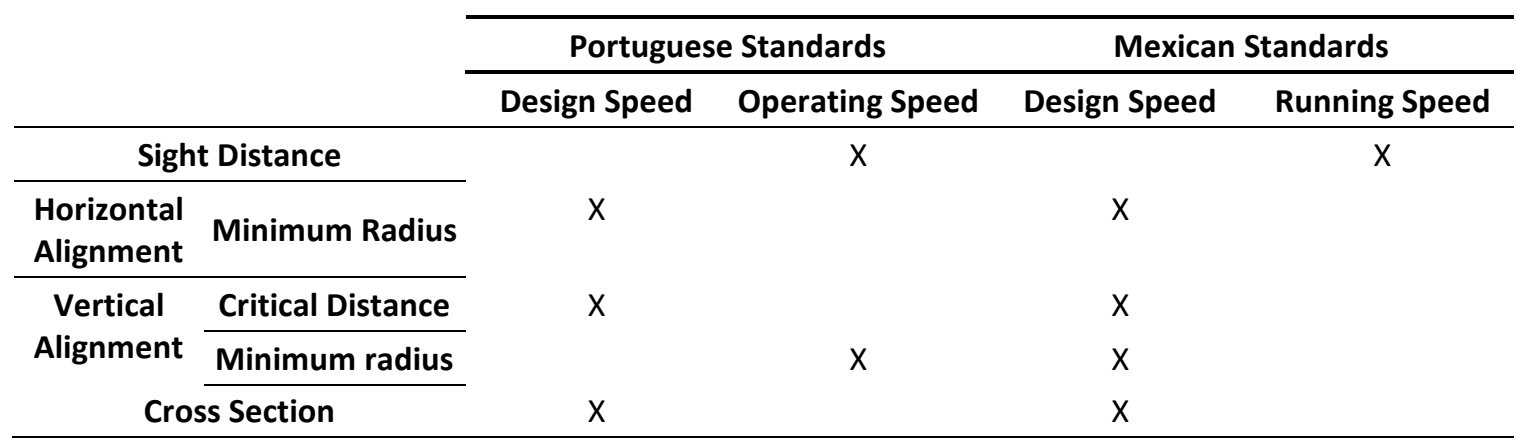

Table 1: Consideration of speed in calculations

\begin{tabular}{lcccc}
\hline Design Speed & 80 & 90 & 100 & 110 \\
\cline { 1 - 5 } Operating Speed & 100 & 110 & 120 & 125 \\
\cline { 1 - 3 } Running Speed & 71 & 79 & 86 & 92 \\
\hline
\end{tabular}

Table 2: Relationship between different speeds [ $\mathrm{km} / \mathrm{h}]$

The sight distance is the driver's ability to see ahead and has the utmost importance in safety. This parameter is commonly associated with the stopping sight distance, which is the distance needed from the instant when a driver sees an obstacle to the instant that the vehicle stops. It depends upon the speed, brake reaction time and coefficients of longitudinal grip.

Notwithstanding, Portuguese standards also consider the decision sight distance, which is related to the stopping sight distance. It is particularly significant at interchange locations, at changes in cross section such as toll plazas and lane drops, and for approximations to service areas where drivers need to make complex or prompt decisions. It depends on the speed and the pre-manoeuvre and manoeuvre time, which are normally fixed to 12 seconds. Table 3 indicates the minimum sight distance, depending upon the design speed.

\begin{tabular}{cccc}
\hline $\begin{array}{c}\text { Design Speed } \\
{[\mathrm{km} / \mathrm{h}]}\end{array}$ & \multicolumn{2}{c}{ Portuguese Standards } & Mexican Standards \\
\cline { 2 - 4 } & Stopping Sight Distance & Decision Sight Distance & Stopping Sight Distance \\
\hline $\mathbf{8 0}$ & 180 & 330 & 115 \\
\hline 90 & 220 & 370 & 135 \\
\hline 100 & 250 & 400 & 155 \\
\hline 110 & 280 & 410 & 175 \\
\hline & & Table 3: Minimum admissible values of sight distance [m]
\end{tabular}

The analysis of the preceding table indicates that Mexican standards are less conservative than Portuguese. Taking into account the speeds considered (Table 1), the Mexican standards use a running speed that is far lower than the operating speed used in the Portuguese standards (Table 2). This single consideration is enough to compromise the values of sight distance, meaning that the Portuguese standard may accrue safer freeway sections.

Regarding the horizontal alignment, there are geometric parameters that limit the design of straight sections, circular curves and transition curves.

With respect to the straight sections, the analysis showed that Portuguese standards require a minimum distance between successive curves of 5 seconds in the design speed settled initially; the Mexican standards do not have restraints. 
With respect to circular curves, the radius ( $r$ ) is the key constraint and depends mostly on the side friction factor, design speed and superelevation, which notably varies due to the climate and weather conditions: $7 \%$ and $10 \%$ for Portugal and Mexico, respectively. Instead of radius, the Mexican standards generally mention the degree of curvature as 20 meters of arc length, but Table 4 shows the conversion. As opposed to Mexico, Portugal largely uses the comfort radius, where the centrifugal acceleration in the curve is restrained to 1.08 $\mathrm{m} / \mathrm{s}^{2}$. In Table 4, the variation of the radius between these two countries is also significant. For instance, for a Mexican freeway designed for $110 \mathrm{~km} / \mathrm{h}$, the radius is someway equivalent to a Portuguese freeway designed for $80 \mathrm{~km} / \mathrm{h}$ because the comfort restriction is applied in almost every case.

\begin{tabular}{cccc}
\hline $\begin{array}{c}\text { Design Speed } \\
{[\mathrm{km} / \mathrm{h}]}\end{array}$ & \multicolumn{2}{c}{ Portuguese Standards } & Mexican Standards \\
\cline { 4 - 4 } & Safety Radius & Comfort Radius & Safety Radius \\
\hline $\mathbf{8 0}$ & 240 & 450 & 208 \\
\hline 90 & 320 & 550 & 270 \\
\hline 100 & 420 & 700 & 353 \\
\hline 110 & 560 & 850 & 417 \\
\hline
\end{tabular}

Table 4: Minimum admissible values of radius [m]

With respect to the transition curves analysis, a spiral curve is normally used in both countries, but there are still differences with respect to its design. Because freeways are usually designed with high radius, the Mexican standards discard the use a transition curve (see Table 5).

\begin{tabular}{lcccc}
\hline Design Speed [km/h] & 80 & 90 & 100 & 110 \\
\hline Portuguese Standards & & 2500 & & 5000 \\
\cline { 1 - 1 } Mexican Standards & 458 & 573 & 764 & 917
\end{tabular}

Table 5: Maximum radius for use of a spiral curve transition [m]

The minimum length or the factor A confines spiral curves. In Portugal, freeway design usually refers to the parameter as $A$, while in Mexico, it is the minimum length. The factor $A$ is a constant parameter and depends on the length and the radius of the curve (equation 1 ).

$$
A^{2}=1 * r
$$

where: $\mathrm{A}$ is the constant parameter [m]

$I$ is the length of the curve in the locus [m] $r$ is the radius of the curve in the locus [m]

Table 6 presents the spiral curve design criteria. The first criterion is related to safety and comfort and was proposed by W. H. Shortt in 1909 (considered in Portuguese standards) and was furthered developed by M.V. Smirnoff in 1949 (considered in Mexican standards). The second criterion is related to the superelevation attainment, of which the lower bound pertains to geometry and the higher bound to hydroplaning. The lower bound superelevation criterion presented in the Mexican Standards was developed by Mexico SCT (1991). The third criterion is common to both countries and requires at least two seconds for the transition curve. The fourth criterion concerns the optical comfort and is only considered by Portugal. 


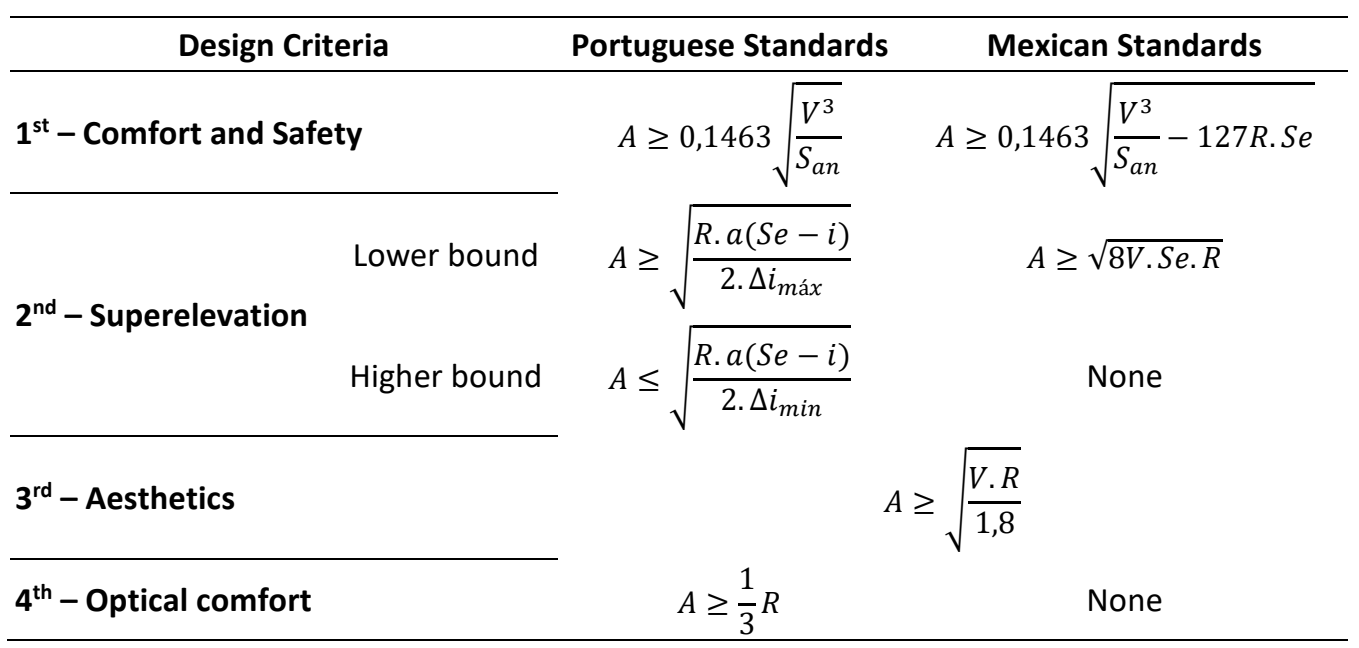

Table 6: Spiral curve design criteria

where: $A$ is the constant parameter $[\mathrm{m}]$

$\mathrm{V}$ is the speed considered $[\mathrm{km} / \mathrm{h}]$

$R$ is the minimum radius of the curve [m]

$\mathrm{S}_{\mathrm{an}}$ is the rate of change in lateral acceleration $\left[\mathrm{m} / \mathrm{s}^{3}\right]$

$\mathrm{S}_{\mathrm{e}}$ is the superelevation [\%]

$i$ is the cross slope [\%]

$\Delta \mathbf{i}$ max and $\Delta \mathbf{i}$ min are the maximum and minimum slope, respectively, in superelevation linear attainment [\%]

Concerning each design speed and the respective minimum radius of the circular curve (Table 4), the minimum admissible values for the parameter A (used in Portugal's design) and the minimum length of the spiral (used in Mexico's design) are presented in Table 7.

\begin{tabular}{|c|c|c|c|c|c|c|}
\hline & & Design Speed [km/h] & 80 & 90 & 100 & 110 \\
\hline \multirow{3}{*}{ Parameter A } & \multicolumn{2}{|l|}{ Portuguese Standards } & 150 & 183 & 283 & 283 \\
\hline & \multirow{2}{*}{ Mexican Standards } & Median Width $<8 \mathrm{~m}$ & 150 & 181 & 219 & 250 \\
\hline & & Median Width $\geq 8 \mathrm{~m}$ & 115 & 139 & 168 & 191 \\
\hline \multirow{3}{*}{$\begin{array}{l}\text { Minimum } \\
\text { Length }\end{array}$} & \multicolumn{2}{|l|}{ Portuguese Standards } & 50 & 61 & 78 & 94 \\
\hline & \multirow{2}{*}{ Mexican Standards } & Median Width $<8 \mathrm{~m}$ & 109 & 122 & 136 & 150 \\
\hline & & Median Width $\geq 8 \mathrm{~m}$ & 64 & 72 & 80 & 88 \\
\hline
\end{tabular}

Table 7: Minimum values of parameter $A[\mathrm{~m}]$ and length [m] for each design speed

Regarding the vertical alignment, it is constituted of grades, crest and sag curves. The minimum grade limit is $0.5 \%$ for both countries, while the maximum depends upon terrain and design speed. For a consistent topography, the Portuguese standards limit it to $6 \%$ (80 $\mathrm{km} / \mathrm{h})$ and $4 \%(110 \mathrm{~km} / \mathrm{h})$. The Mexican standards limit it to $4 \%(80 \mathrm{~km} / \mathrm{h})$ and $3 \%(110$ $\mathrm{km} / \mathrm{h})$. With respect to the critical distance that determines the truck lanes, from Table 8 , it seems that Portugal is more conservative than Mexico, meaning that Portugal is more easily conditioned to design additional lanes for trucks.

\begin{tabular}{|c|c|c|c|c|c|c|}
\hline & \multirow{2}{*}{$\begin{array}{l}\text { Initial Speed } \\
{[\mathrm{km} / \mathrm{h}]}\end{array}$} & \multirow{2}{*}{$\begin{array}{c}\text { Reduction } \\
{[\mathrm{km} / \mathrm{h}]}\end{array}$} & \multicolumn{4}{|c|}{ Grade } \\
\hline & & & $2 \%$ & $3 \%$ & $4 \%$ & $5 \%$ \\
\hline Portuguese Standards & 90 & 15 & $\infty$ & 420 & 300 & 230 \\
\hline Mexican Standards & 92 & 25 & 1853 & 627 & 400 & 300 \\
\hline
\end{tabular}

Table 8: Minimum admissible values of critical distance for vertical alignment 
Based on the crest and sag curves standard analysis, the minimum radii are shown in Table 9. As for the horizontal alignment, the Portuguese standards endorse the use of comfort radius.

\begin{tabular}{|c|c|c|c|c|c|}
\hline \multirow{3}{*}{$\begin{array}{c}\text { Design } \\
\text { Speed } \\
{[\mathrm{km} / \mathrm{h}]}\end{array}$} & \multicolumn{3}{|c|}{ Sag Curves } & \multicolumn{2}{|c|}{ Cres Curves } \\
\hline & \multicolumn{2}{|c|}{ Portuguese Standards } & \multirow{2}{*}{$\begin{array}{c}\text { Mexican Standards } \\
\text { Safety Radius }\end{array}$} & \multirow{2}{*}{$\begin{array}{c}\text { Portuguese Standards } \\
\text { Safety Radius }\end{array}$} & \multirow{2}{*}{$\begin{array}{c}\text { Mexican Standards } \\
\text { Safety Radius } \\
\end{array}$} \\
\hline & Safety Radius & Comfort Radius & & & \\
\hline 80 & 5000 & 6000 & 3100 & 3500 & 2500 \\
\hline 90 & 7500 & 8500 & 4300 & 4500 & 3100 \\
\hline 100 & 9000 & 12500 & 5700 & 5500 & 3700 \\
\hline 110 & 12000 & 13000 & 7200 & 6000 & 4300 \\
\hline
\end{tabular}

Table 9: Minimum admissible values of radius for vertical alignment [m]

The parameters used for cross sections are described in Table 10.

\begin{tabular}{|c|c|c|c|c|c|}
\hline & $\begin{array}{l}\text { Cross } \\
\text { Slope }\end{array}$ & $\begin{array}{c}\text { Max. } \\
\text { Superelevation }\end{array}$ & $\begin{array}{l}\text { Lanes } \\
{[\mathrm{m}]}\end{array}$ & $\begin{array}{l}\text { Shoulder } \\
\text { Ext / Int [m] }\end{array}$ & $\begin{array}{c}\text { Medians } \\
\text { With Barriers / Without Barriers [m] }\end{array}$ \\
\hline Portuguese Standards & $2.5 \%$ & $7 \%$ & 3.75 & $3.00 / 1.00$ & $1.50 / 11.50$ \\
\hline Mexican Standards & $2.0 \%$ & $10 \%$ & 3.50 & $3.00 / 1.00$ & $1.00 / 8.00$ \\
\hline
\end{tabular}

Table 10: Minimum admissible values of parameters for cross sections

The literature review revealed several similarities because each element of design is based on common design theories; however, significant differences occurred between the minimum admissible values for geometric parameters mainly because there are priorities that balance between safety and comfort, which may be reflected in economic aspects.

\subsection{Multi-criteria analysis}

The following method is a multi-criteria analysis, whose major goal is the selection of the best freeway design according to the standard design used (Mexican or Portuguese). This multi-criteria analysis is inspired by Kalamaras et al. (2000), selecting the best alignment by considering four main objectives: minimize construction problems, maximize operational functionality, minimize environmental impact and maximize results of the economic investment.

The following multi-criteria analysis is a proposal extended with criteria that most benefit the operational functionality objective. To define the criteria, a hierarchical process was performed using expert and stakeholders' (GEG) opinions with sensibility analysis.

The first hierarchic level of these criteria is the same as that of Kalamaras' analysis and represents the stakeholders. The first criterion $(A)$ represents the civil engineer that designs the alignments. The next (B) represents the concessionary company responsible for maintenance, with concerns related to safety, such as drainage, skidding and road safety. The drivers are taken into account in the last criterion (C), which considers discomfort and costs. The subsequent proposed levels are original and include design parameters criteria that are linked to respective stakeholder concerns.

This analysis used the comparison method to assign the weights and is sustained by the previous analysis of the Mexican and Portuguese standards. Table 11 presents the weights of each criteria. 


\begin{tabular}{|c|c|c|c|}
\hline Kalamaras' weights & & Proposed multi-criteria analysis & \\
\hline \multirow{7}{*}{$\begin{array}{c}\text { A. Alignment } \\
\text { Geometry Design } \\
30 \%\end{array}$} & \multicolumn{2}{|l|}{ A1. Design Speed } & $10.0 \%$ \\
\hline & \multicolumn{2}{|l|}{ A2. Freeway Length } & $4.0 \%$ \\
\hline & \multirow[t]{2}{*}{ A3. Monotony } & A3.1. Length straight/curve & $7.0 \%$ \\
\hline & & A3.2. Critical straight length & $2.0 \%$ \\
\hline & \multicolumn{2}{|c|}{ A4. Alignment homogeneity } & $3.0 \%$ \\
\hline & \multirow{2}{*}{$\begin{array}{l}\text { A5. Comfort and } \\
\text { Aesthetics }\end{array}$} & A5.1. Aesthetics (Spiral design) & $2.0 \%$ \\
\hline & & A5.2. Optical comfort (Spiral design) & $2.0 \%$ \\
\hline \multirow{15}{*}{$\begin{array}{c}\text { B. Safety } \\
50 \%\end{array}$} & \multirow[t]{4}{*}{ B1. Visibility } & B1.1. Stopping Sight Distance & $7.5 \%$ \\
\hline & & B1.2. Decision Sight Distance & $5.0 \%$ \\
\hline & & B1.3. Minimum sight obstruction distance & $2.0 \%$ \\
\hline & & B1.4. Height of driver's eye and object & $3.0 \%$ \\
\hline & \multirow[t]{3}{*}{ B2. Drainage } & B2.1. Sag vertical curves (minimum radius) & $3.0 \%$ \\
\hline & & B2.2. Area & $5.0 \%$ \\
\hline & & B2.3. Attainment of superelevation & $6.5 \%$ \\
\hline & \multirow[t]{4}{*}{ B3. Accelerations } & B3.1. Radius & $2.0 \%$ \\
\hline & & B3.2. Comfort limitation & $1.5 \%$ \\
\hline & & B3.3. Superelevation & $1.5 \%$ \\
\hline & & B3.4. Radial uncompensated acceleration & $5.0 \%$ \\
\hline & \multirow[t]{2}{*}{ B4. Skid } & B4.1. Internal curve skid & $1.5 \%$ \\
\hline & & B4.2. External curve skid & $1.5 \%$ \\
\hline & \multirow[t]{2}{*}{ B5. Insafety } & B5.1. Intersections & $3.0 \%$ \\
\hline & & B5.2. Sudden slowdowns & $2.0 \%$ \\
\hline \multirow{3}{*}{$\begin{array}{l}\text { C. User perspective } \\
20 \%\end{array}$} & \multicolumn{2}{|l|}{ C1. Level of discomfort } & $5.0 \%$ \\
\hline & C2. Costs & C2.1. Traffic level ensured & $13.0 \%$ \\
\hline & & C2.2. Tolls & $2.0 \%$ \\
\hline
\end{tabular}

Table 11: Synthesis of criteria (design parameters) and weights of this multi-criteria

The score in this analysis corresponds to values between zero $(0)$ and three $(+3)$, i.e., critical and ideal, respectively. Negative punctuation is considered inadequate, for example, in case studies whose standard did not consider a specific parameter; as a result, the worst value is null (0). The assignment of the scores is fully explained in Pereira (2014).

\section{Case Studies}

To compare the outcome design reliably, six case studies were designed using the AutoCAD Civil 3D software for a single mountainous topography of Xalapa (Mexico) with fixed points in the horizontal and vertical alignment. Figure 1 shows an example of a horizontal alignment case study and Figure 2 shows an example of a vertical alignment case study (note that the last grade depends on the last point due to the length).

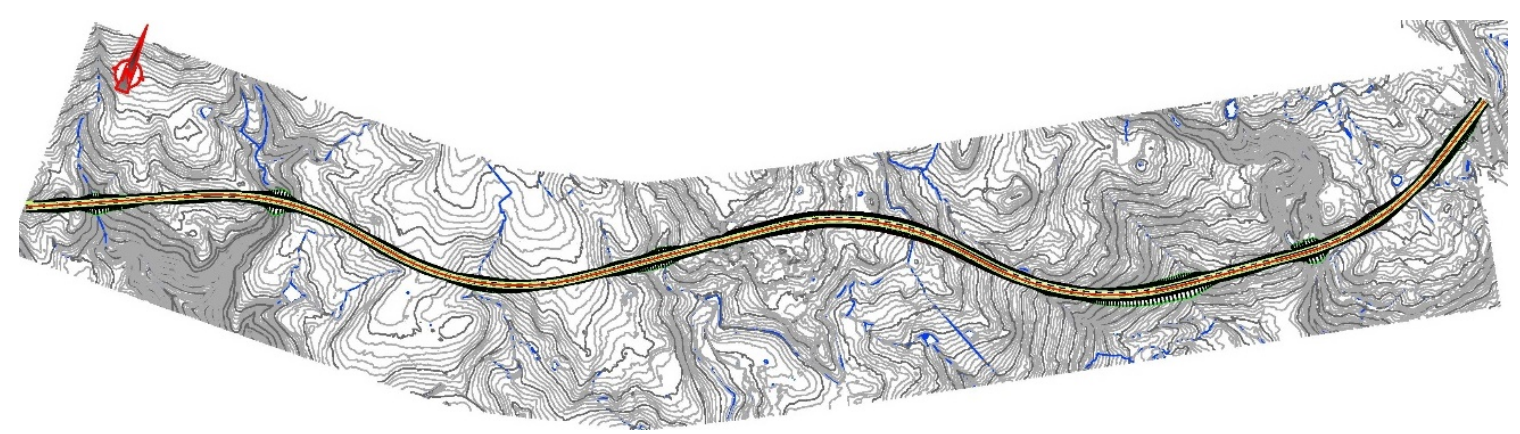

Figure 1: Example of a horizontal alignment case study design 


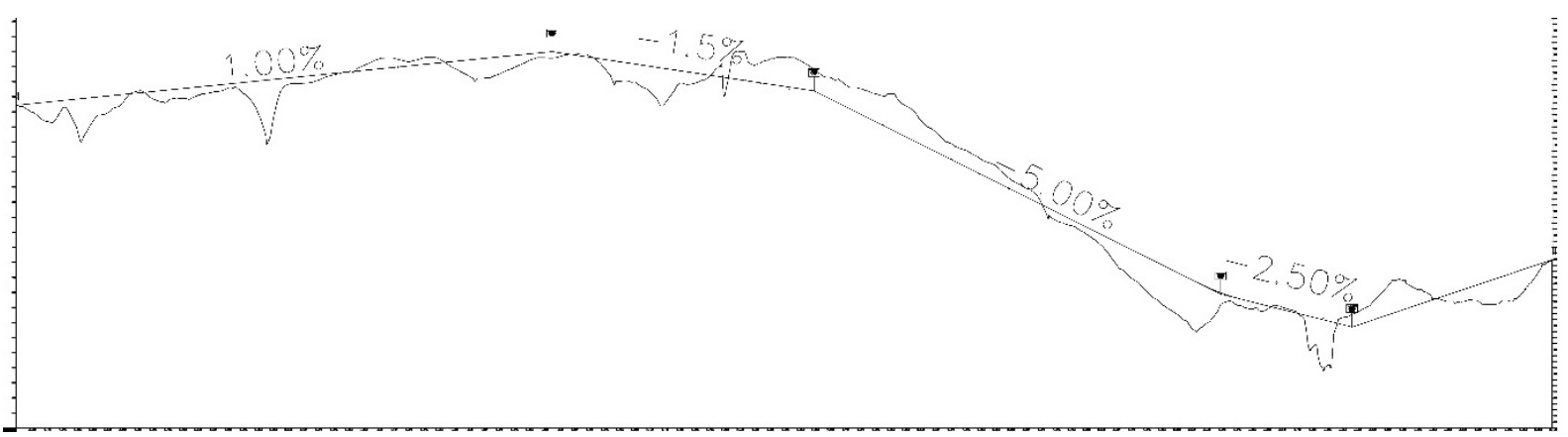

Figure 2: Example of a vertical alignment case study design

For each design speed, i.e., $80 \mathrm{~km} / \mathrm{h}$ (min speed) and $110 \mathrm{~km} / \mathrm{h}$ (max speed), a case designed with the Portuguese standards and another with the Mexican standards were analysed, analogous to the safety approach. Additionally, the comfort approach, which only the Portuguese standards take into account, was studied. The few geometric parameters that differ between the case studies are given in Table 12 .

\begin{tabular}{ccc}
\hline Horizontal Alignment & Vertical Alignment & Cross Section \\
\hline Minimum Radius of Circular Curves & Radius of Vertical Curves & Cross Slope \\
Superelevation (7\% for Portugal, 10\% for Mexico) & Last Grade & Lanes width \\
Length of Attainment of Superelevation (linear) & - & Width of Shoulders \\
Length of Transition Curve (Spiral) & - & Width of Medians \\
\hline
\end{tabular}

Table 12: Varying geometric parameters of case studies

\subsection{Design outcome comparison}

Regarding the horizontal alignment displayed in Figure 3, the parameters combination led to the design line similarity of a Portuguese freeway, designed for $80 \mathrm{~km} / \mathrm{h}$ with the comfort approach, and a Mexican freeway, designed for $110 \mathrm{~km} / \mathrm{h}$ with the safety approach.

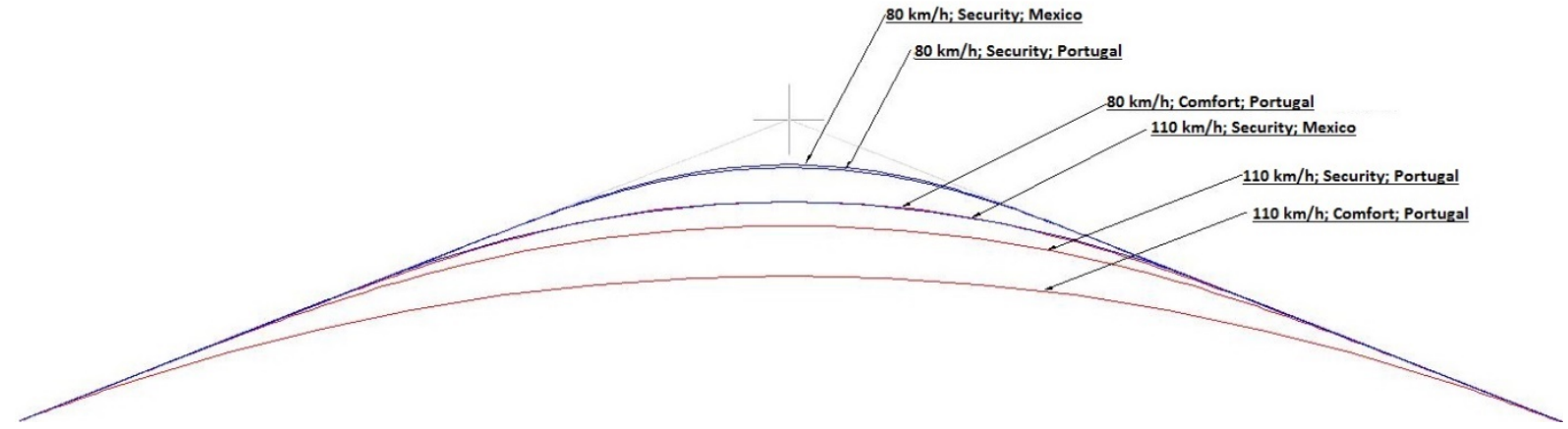

Figure 3: Horizontal alignment design comparison

Regarding the radial uncompensated acceleration analysis, which is somehow a measure of comfort, Table 13 presents the results of the case studies. For each design speed, the two case studies designed with the Portuguese standards revealed lower values of radial uncompensated acceleration than those of the Mexican case study. It is concluded that the Portuguese standards lead to a more comfortable freeway flow than the Mexican standards for the same speed design. 


\begin{tabular}{cc}
\hline $\begin{array}{c}\text { Case study } \\
\text { [Design Speed; Approach; Standard] }\end{array}$ & $\begin{array}{c}\text { Radial uncompensated acceleration } \\
{\left[\mathbf{m} / \mathbf{s}^{2}\right]}\end{array}$ \\
\hline $80 \mathrm{~km} / \mathrm{h}$; Safety; Mexico & 1.39 \\
$80 \mathrm{~km} / \mathrm{h}$; Safety; Portugal & 1.37 \\
$80 \mathrm{~km} / \mathrm{h}$; Comfort, Portugal & 0.41 \\
$110 \mathrm{~km} / \mathrm{h}$; Safety; Mexico & 1.26 \\
$110 \mathrm{~km} / \mathrm{h}$; Safety; Portugal & 0.98 \\
$110 \mathrm{~km} / \mathrm{h}$; Comfort, Portugal & 0.41 \\
\hline
\end{tabular}

Table 13: Maximum values of radial uncompensated accelerations for curves [m/s2]

The Brückner curve characterizes the earthworks and is usually related to the economy once there is a higher impact on costs. In Figure 4, the analysis of the case studies reveals that for consistent terrain, the standards impact is null, while for irregular topography or rough terrain (after Pk 3+000), the differences between the curves increase.

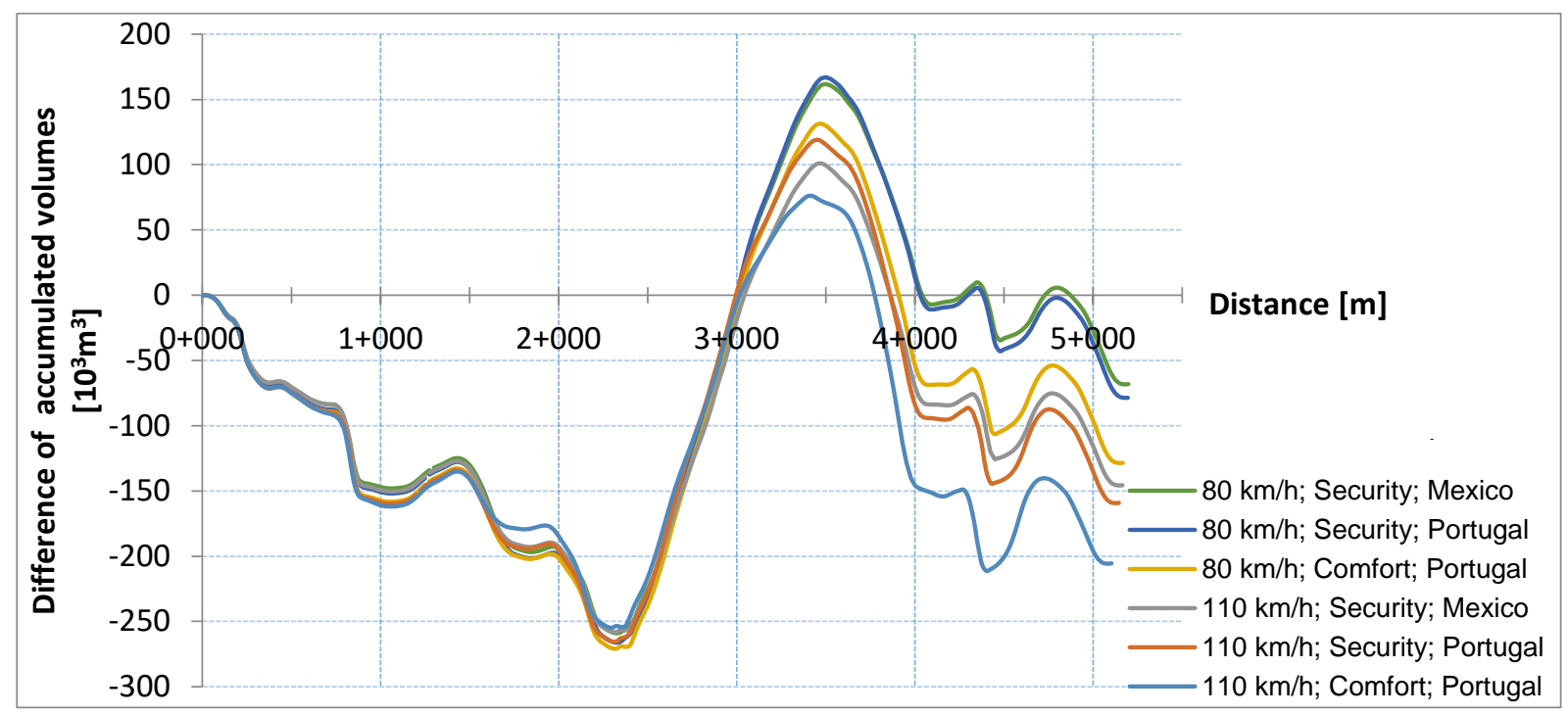

Figure 4: Comparison of Brückner curves of case studies

Through the curves analysis, it is revealed that Mexico's design produced less difference with respect to accumulated earthworks than the Portuguese design, apart from the design speed. It may be concluded that the Mexican standards aim to design more economic freeways.

\subsection{Multi-criteria analysis results}

The multi-criteria analysis applied in the case studies reveals the impact of standards via a sensibility analysis that takes into account three criteria: alignments geometry, safety, and user perspective. The strategy matrix includes the combinations considered, i.e., the case studies designed, and the decision matrix has already been normalized by Pereira (2014). Table 10 shows the results of the case studies through the proposed quantitative method.

\begin{tabular}{|c|c|c|c|c|c|}
\hline $\begin{array}{c}80 \mathrm{~km} / \mathrm{h} ; \\
\text { Safety; Mexico }\end{array}$ & $\begin{array}{c}80 \mathrm{~km} / \mathrm{h} ; \\
\text { Safety; Portugal }\end{array}$ & $\begin{array}{l}80 \mathrm{~km} / \mathrm{h} \text {; } \\
\text { Comfort; } \\
\text { Portugal }\end{array}$ & $\begin{array}{c}110 \mathrm{~km} / \mathrm{h} ; \\
\text { Safety; Mexico }\end{array}$ & $\begin{array}{c}110 \mathrm{~km} / \mathrm{h} ; \\
\text { Safety; Portugal }\end{array}$ & $\begin{array}{c}110 \mathrm{~km} / \mathrm{h} ; \\
\text { Comfort; } \\
\text { Portugal }\end{array}$ \\
\hline $31.1 \%$ & $45.7 \%$ & $53.6 \%$ & $51.5 \%$ & $64.3 \%$ & $71.9 \%$ \\
\hline
\end{tabular}

Table 14: Results of multi-criteria analysis for the six case studies, designed as [Design Speed; Approach; Standard]

In general, the Portuguese case studies revealed better scores in comparison with the Mexican case studies, indicating a better methodology for freeway design. Once more, the 
similarity that relates a Portuguese freeway designed for $80 \mathrm{~km} / \mathrm{h}$ (comfort approach, which is the custom in Portugal) to a Mexican freeway designed for $110 \mathrm{~km} / \mathrm{h}$ (safety approach) is shown. Their scores were very similar, although the Portuguese case had a $2 \%$ greater final score, indicating a strong, unlikely similarity.

\section{Conclusions}

Highway design, particularly freeway design, has several similarities around the world but also significant differences depending on the regulations applied. Each set of standards balances safety and comfort through the design parameter restraints.

In this study, it is concluded that the Portuguese standards lead to wider and extensive freeways that arise from higher restrictions in the minimum values of geometric parameters. It is also concluded, through a Brückner curves analysis, that the Mexican standard minimum values result in more economic freeways. Thus, there must be a sense of balance between the comfort constraint, which leads to safer and more comfortable freeway flow, and the safety constraint, which leads to more economic construction.

Conclusively, the discrepancy between both countries' priorities is notable: a Portuguese freeway designed for $80 \mathrm{~km} / \mathrm{h}$ satisfies all requirements of a maximum speed freeway in Mexico designed for $110 \mathrm{~km} / \mathrm{h}$.

This contrast occurs mainly because the comfort constraint has major importance, which is increased by time and economic development. Therefore, roadway expansion is a consequence of the global progress of human civilization and is normally fostered by economic and social pressure.

\section{References}

AASHTO. 2011. Policy on Geometric Design of Highways and Streets (6th Edition) with 2012 Errata. Vol. 6th ed. Washington, DC: American Association of State Highway and Transportation Officials (AASHTO).

ERF. 2015. European Road Statistics Yearbook 2014-2015. Brussels, Belgium: European Union Road Federation.

Gabinete de Estruturas e Geotecnia, Lda. GEG. http://www.geg.pt/.

InIR. 2008. Auto-estradas - Características técnicas. In Instituto de Infra-Estruturas Rodoviárias, edited by Eng. João Bernardo Pessoa Begonha. Lisboa, Portugal: Instituto de Infra-Estruturas Rodoviárias IP.

InIR. 2010. Norma de Traçado - Revisão. In Instituto de Infra-Estruturas Rodoviárias, edited by ENGIVIA and LNEC. Lisboa, Portugal: Instituto de Infra-Estruturas Rodoviárias IP.

JAE. 1994. Norma de Traçado. In Junta Autónoma de Estradas, edited by Portugal Almada. Portugal: Junta Autónoma de Estradas.

Kalamaras, G. S., L. Brino, G. Carrieri, C. Pline, and P. Grasso. 2000. "Application of Multicriteria Analysis to select the best highway alignment." Tunnelling and Underground Space Technology 15 (4):415-420. DOI: 10.1016/S0886-7798(01)00010-4.

Pacheco, Elsa. 2001. "Alteração das acessibilidades e dinâmicas territoriais na Região Norte: expectativas, intervenções e resultantes." PhD, Universidade do Porto.

Pereira, Lígia. 2014. "Projeto de Autoestradas do México: Comparação com o Caso Português." Master, Department of Civil Engineering, Faculty of Engineering - University of Porto.

PRN. 2000. Plano Rodoviário Nacional aprovado pelo Decreto-Lei n. 222/98 de 17 de Julho (D.R. I Série-A n.o 163), rectificado pela Declaração de Rectificação n. 19-D/98 (D.R. I 
Série-A n.o 252), pela Lei no. 98/99 de 26 Julho (D.R. I Série-A n.o 172) e pelo Decreto-Lei n.o 182/2003 de 16 de Agosto (D.R. I Série-A n.o 188).

SCT. 1984. Normas de Servicios Técnicos - Proyecto Geométrico de Carreteras. México: Secretaría De Comunicaciones Y Transportes.

SCT. 1991. Manual de proyecto Geométrico de Carreteras. México: Secretaría De Comunicaciones Y Transportes.

SCT. 2004. Recomendaciones de Actualizacion de Algunos Elementos del Proyecto Geométrico de Carreteras. México: Secretaría De Comunicaciones Y Transportes.

Vahrenkamp, Richard. 2010. The German Autobahn, 1920-1945: Hafraba Visions and Mega Projects: BoD-Books on Demand.

\section{Acknowledgements}

First author acknowledges fruitful discussions with Eng. Rui Correia and Eng. Luís Gonçalves, from GEG (Gabinete de Estruturas e Geotecnia), a Portuguese consultancy company. 